International Research Journal of Management, IT \& Social Sciences
Available online at https://sloap.org/journals/index.php/irjmis/
Vol. 7 No. 6, November 2020, pages: 96-108
$\begin{aligned} & \text { ISSN: 2395-7492 } \\ & \text { https://doi.org/10.21744/irjmis.v7n6.1016 }\end{aligned}$

\title{
Effect of Investment, GRDP Percapita, and Original Local Government Revenue on Regional Financial Independence through Capital Expenditure as Intervening Variables
}

Article history:

Submitted: 09 August 2020

Revised: 18 September 2020

Accepted: 27 October 2020

Keywords:

capital expenditure; financial independence; government revenue; investment;

original local;

\begin{abstract}
This study aims to see the significance of investment, GDRP per capita, Original Local Government Revenue on regional finance independence. This population in this study were districts/cities in Bali Province from 2014 to 2018. This study used a sample with the census method. The data analysis technique used is path analysis. These results showed that investment has a positive and insignificant effect on capital expenditure and has a positive and significant effect on regional finance independence, GRDP per capita has a significant negative effect on capital expenditure and has a significant positive effect on regional financial independence, Original Local Government Revenue (PAD) has a significant positive effect on regional financial independence while the positive and insignificant effect of capital expenditure on regional financial independence.
\end{abstract}

International research journal of management, IT and social sciences $(0) 2020$. This is an open access article under the CC BY-NC-ND license (https://creativecommons.org/licenses/by-nc-nd/4.0/).

Corresponding author:

Diana Yusiawati,

Economics and Business,

Udayana University, Denpasar, Indonesia.

Email address: d.yusiawati@gmail.com

\footnotetext{
Economics and Business Faculty, Udayana University, Denpasar, Indonesia Economics and Business Faculty, Udayana University, Denpasar, Indonesia 


\section{Introduction}

Increasing economic growth is one of the development targets at both the national and regional levels. According to Law Number 32 of 2004 concerning the balance of central to regional finance, it is indicated that regional governments in managing their households need to be provided with sources of income or regional financial revenue to finance all activities in the context of implementing government and development tasks for the welfare of society as a wholly fair and equitable.

Halim (2004), explains that in the context of regional autonomy in Indonesia, the budget management process has very broad implications for the implementation of various regional government policies, both economically and politically. Each region has a different proportion of financial policy problems, taking into account various factors such as the financial capacity of the region, the social and economic structure of the population, culture, politics, and the prevailing regulations of the central government. In carrying out regional autonomy, regional governments are required to run government effectively and efficiently, be able to encourage community participation in development, increase equity and community justice in development and increase equity and justice by developing all the potentials of each region. An autonomous region is expected to be able and independent in financing its regional government activities with a lower proportion of dependence on the central government compared to the original local government revenue (PAD). Regional financial independence is the financial capacity of the region in financing regional expenditures through the large contribution of each source of original local government revenue (PAD) to total original local government revenue (PAD) and the effectiveness of planning targets on its realization (Rante \& Praminto, 2017; Narayan, 2005; Hamdi \& Sbia, 2013).

Regional expenditure is an estimate of the burden of regional expenditure which is allocated fairly and evenly so that it can relatively be enjoyed by all groups of society without discrimination, especially in the provision of public services (Kawedar et al., 2008). According to Badruddin (2012), he explains that regional government expenditure in the form of routine expenditure consisting of apparatus expenditure or indirect expenditure and development expenditure consisting of public expenditure or direct spending will generate demand for goods and services which are then responded to by producers. Local government spending is measured by the total operational expenditure and capital expenditure allocated in the regional budget. The greater the productive local government spending. In the regional economy, the investment can be a driving force for product development so that the resulting output is getting better. In economics, there is a term "there is no (economic) growth without investment". This statement implies that investment has an important role in economic development, even though investment is not the only component of economic growth (Liu, 2002; Sunariani et al., 2019). In economic development, investment has two important roles in the macroeconomy, namely its effect on aggregate demand so that it will boost output and employment opportunities and their impact on capital formation. The investment will add various equipment, machines, and buildings, and so on. In the long term, this action will increase potential output, and promote sustainable economic growth, both through domestic investment projects (PMDN) and foreign investment projects (PMA).

According to Romhadhoni et al. (2018), one of the indicators of the success of development implementation that can be used as a macro benchmark is economic growth which is reflected in changes in GRDP (Gross Regional Domestic Product) in an area. GRDP is defined as the amount of added value generated by all business units in an area or is the total value of the final goods and services produced by all economic units in an area. Todaro \& Smith (2008), explained that the higher the economic growth of a region, the better the regional economic activity. The regional economic growth is indicated by the GRDP growth rate at constant prices. Increasing economic growth is marked by the increase in the production of the types of services and goods produced so that they can absorb large numbers of workers and have an impact on reducing the number of unemployed and poverty. The benchmarks for measuring the success rate of budget realization in regional economic development are the increase in GDP growth and the increase in the potential of regional economic resources as measured by the ratio of original local government revenue (PAD) to total regional revenue. The measure of the success of budget execution explains that regional financial management that is carried out economically, efficiently, and effectively or fulfills the principles of value for money as well as participation, transparency, accountability, and justice will be able to encourage economic growth. Good regional financial management does not only require reliable human resources but also must be supported by adequate regional financial capacities. One of the levels of regional financial capacity can be measured by the amount of regional revenue, especially local revenue. Regional financial capacity in the era of regional autonomy is often measured using Original Local Government Revenue (PAD). The size of the Original Local Government Revenue (PAD) is often associated with the success of the region in implementing regional autonomy. Local taxes and levies, which are the biggest contributors to Original Local Government Revenue (PAD), should be able to finance local government spending (Adi,

Yusiawati, D. ., \& Marhaeni, A. . (2020). Effect of investment, GRDP percapita, and original local government revenue on regional financial independence through capital expenditure as intervening variables. International Research Journal of Management, IT and Social Sciences, 7(6), 96-108. https://doi.org/10.21744/irjmis.v7n6.1016 
2006). Therefore, the investment made to establish regional revenue can be made through (1) the pattern of intensification and extensification of original regional income, which is to emphasize regional tax and retribution revenues; (2) investment in businesses in the upstream and downstream sectors in the structure of the local economy, in which local governments participate in business activities based on professional investment analysis to gain profit for increasing Original Local Government Revenue (PAD) which is generally carried out by Regional-Owned Enterprises (BUMD).

Investments made by regions and in cooperation with third parties in the form of equity participation or utilization of regional assets can generate revenue gains. In this way, regions through their investment capabilities can increase the amount of Original Local Government Revenue (PAD) as an indicator of pro-investment areas. This Original Local Government Revenue (PAD) can be obtained from investment profits made both short-term and long-term investments. However, investment returns in the regions can be measured by how much Regional Original Income is obtained. So the original regional income should have come from the impact of investment in the regions, which means that the Regional Revenue and Expenditure Budget (APBD) has the power of a source of funds that is very supportive of investment in which the Regional Income and Expenditure Budget depends on Regional Original Income, not on Funds. Special Allocation (DAK) and General Allocation Fund (DAU). By largely depending on Regional Original Income, an area can be said to be independent and worthy of being a pro-investment region.

Table 1

Calculation of the regional independence ratio of Bali province

The fiscal year 2014 - 2018

(in thousand rupiahs)

\begin{tabular}{llll}
\hline Year & $\begin{array}{l}\text { Original Local } \\
\text { Government Revenue }\end{array}$ & Total Income & $\begin{array}{l}\text { Regional Independence } \\
\text { Ratio }\end{array}$ \\
\hline 2014 & 2.920 .416 .697 & 4.577 .678 .391 & $63,80 \%$ \\
2015 & 3.041 .266 .607 & 4.967 .935 .151 & $61,22 \%$ \\
2016 & 3.041 .195 .258 & 5.249 .017 .754 & $57,94 \%$ \\
2017 & 3.398 .472 .278 & 5.992 .161 .668 & $56.72 \%$ \\
2018 & 3.718 .499 .635 & 6.259 .367 .608 & $59.41 \%$ \\
\hline
\end{tabular}

Source: Bali in Figures, Central Bureau of Statistics of Bali Province, 2020

The development of the level of regional independence in Bali Province in the last 5 years from 2014 to 2018 has decreased every year but in 2018 it has increased. The ratio of regional financial independence of Bali Province for 2014 to 2018 is included in the medium category, which can be seen from the ratio of regional financial independence which is between 50 percent - 75 percent. Based on this value, it can be said that Bali Province has low financial dependence on the Central Government and a participatory relationship pattern in which the role of the central government is diminishing considering that Bali Province is close to being able to carry out autonomous affairs. The Original Local Government Revenue (PAD) of Bali Province has always increased every year. This shows that the Province of Bali can optimize revenue from Original Local Government Revenue (PAD) and revenue/profit for BUMD. The province of Bali is considered to be independent in the implementation of regional autonomy, especially in utilizing potential posts for Original Local Government Revenue (PAD) both intensification and extensification of total regional expenditure.

\section{Hypotheses}

Based on this background, the formulation of the hypothesis in this study is:

1) Does the investment have a significant effect on capital expenditure?

2) Does the GRDP per capita have a significant effect on capital expenditure?

3) Does Original Local Government Revenue (PAD) significantly influence capital expenditure

4) Does the investment have a significant effect on Regional Financial Independence?

5) Does the GRDP per capita have a significant effect on Regional Financial Independence?

6) Does Original Local Government Revenue (PAD) significantly influence Regional Financial Independence

7) Does capital expenditure have a significant effect on Regional Financial Independence? 
8) Does investment indirectly affect regional financial independence with capital expenditure as an intervening variable?

9) Does the GRDP per capita indirectly affect regional financial independence with capital expenditure as an intervening variable?

10) Does Original Local Government Revenue (PAD) indirectly affect regional financial independence with capital expenditure as an intervening variable?

11) What is the trend or trend of Regional Financial Independence in the Regency / City of Bali Province?

\section{Materials and Methods}

This research includes quantitative research. The population of this research is the regencies/cities in Bali Province for the period 2014-2018. Determination of the research sample using the census method, which uses the entire population to be analyzed. There are 8 districts and 1 city in Bali Province, with a total number of observations of 45 observations. Data collection methods used were observation and interviews where data collection was carried out by direct observation and interviews with related parties regarding the issues being reviewed. This study uses path analysis to determine the influence of exogenous and endogenous variables.

\section{Results and Discussions}

The data used in this study is data sourced from the annual financial reports of regencies/cities in Bali Province for the period 2014 to 2018. Based on data from the annual financial reports of local governments, it can be calculated that the ratio used in this study is independent. The results of the tabulation of data for exogenous and endogenous variables can be presented in full in Table 2

Table 2

Descriptive statistics of data

\begin{tabular}{|c|c|c|c|c|}
\hline Variable & Min & Max & Mean & Std. Deviation \\
\hline Investation & 15652,00 & 7065808,00 & 1274905,0493 & 1612389,56268 \\
\hline GRDP per capita & 3688,00 & 35278,50 & 14274,2871 & 8715,40382 \\
\hline Original Local & 76141461,00 & 4555716407,00 & 648642651,9254 & 1028603745,111 \\
\hline \multicolumn{5}{|l|}{ Government } \\
\hline \multicolumn{5}{|l|}{ Revenue } \\
\hline Capital Expenditure & 70217269,00 & 1241111665,00 & 299460182,5 & 259592149,7 \\
\hline $\begin{array}{l}\text { Regional finance } \\
\text { independence }\end{array}$ & 9,57 & 84,47 & 25,3859 & 20,06742 \\
\hline
\end{tabular}

Sources: Data processed, 2020

Table 2 shows the average value (mean) of investment variables in regencies/cities in Bali Province for the study period 2014 - 2018 amounting to 1274905.0493, which is smaller than the standard deviation value of 1612389.56268. The value of the standard deviation of the investment variable is greater than the average value. This shows that there are large fluctuations in the investment variable, sample regency/city-data. The investment variable has a maximum value of 7065808.00. The maximum value indicates that there are regencies/cities in Bali Province that can generate an investment value of Rp. 7,065,808,000,000. The minimum value of 15652.00 indicates that there are districts/cities that have low investment value.

The average (mean) value of the GRDP variable which is proxied by the basis of constant prices according to the business field is 14274.2871 , which is greater than the standard deviation value of 8715.40382 . The standard deviation value that is smaller than the average value indicates low fluctuation in the data on the GRDP variable of regencies/cities in Bali Province. The maximum value of the GRDP variable is 35278.50 indicating that there is a company that has a GRDP value of Rp. 35,279,000,000 of the total District / City GRDP in Bali Province. The GRDP variable has a minimum value of 3688.00 indicating that there is a Regency / City during the study period that has the

Yusiawati, D. ., \& Marhaeni, A. . (2020). Effect of investment, GRDP percapita, and original local government revenue on regional financial independence through capital expenditure as intervening variables. International Research Journal of Management, IT and Social Sciences, 7(6), 96-108. https://doi.org/10.21744/irjmis.v7n6.1016 
smallest value of Rp. 3,688,000,000. This value shows that there is a sample of cities/regencies that have poor economic growth due to their low per capita income.

The average value (mean) of the Original Local Government Revenue variable, which is proxied by the sum of local taxes, local levies, the results of regional property owned and the results of the management of separated regional assets and other legitimate original regional income smaller than the standard deviation value $1028603745,111$.

The standard deviation value that is greater than the average value (mean) indicates that there is a large fluctuation in the data on the variable data of the Original Local Government Revenue in Bali Province. The maximum value of the Original Local Government Revenue variable is 4555716407.00, which indicates that there is a Regency / City that has an Original Local Government Revenue of Rp. 4,555,716,407,000, proving that the region is capable of implementing fiscal decentralization and shows that the region does not depend on the central government. The minimum value of the Original Local Government Revenue variable is 76141461.00 indicating that there is a Regency / City in Bali Province that has the smallest Original Local Government Revenue during the study year, namely Rp. $76,141,461,000$.

The average (mean) value of the capital expenditure variable which is greater than the standard deviation value explains that the capital expenditure variable data has small fluctuations in the capital expenditure variable data of regencies/municipalities in Bali Province which is 299460182.5 which is greater than the standard deviation of 259592149.7. The maximum value of the capital expenditure variable is 1241111665.00 , which explains that some cities/regencies have capital expenditures of Rp. 1,241,111,665,000. The minimum value of the capital expenditure variable is 70217269.00, which explains that some cities/regencies have capital expenditures of Rp. 70,217,269,000. The lower capital expenditures indicate that the opportunities for development and improvement of regional public facilities will be smaller.

Table 3

Regression test results for the equation of sub-structure 1 and sub-structure 2

\begin{tabular}{lccccc}
\hline Path & $\begin{array}{c}\text { Standardized } \\
\text { Coef. Beta }\end{array}$ & Standard t Error & Sig. & & Information \\
\hline $\mathrm{X}_{1} \longrightarrow \mathrm{Y}$ & $-0,104$ & 0,000000516 & $-2,512$ & 0,016 & Significant \\
$\mathrm{X}_{2} \longrightarrow \mathrm{Y}$ & 0,269 & 0,000128727 & $-2,512$ & 0,000 & Significant \\
$\mathrm{X}_{3} \longrightarrow \mathrm{Y}$ & 0,428 & 0,000000003 & 3,261 & 0,002 & Significant \\
$\mathrm{X}_{4} \longrightarrow \mathrm{Y}$ & 0,363 & 0,000000009 & 2,963 & 0,005 & Significant \\
$\mathrm{X}_{1} \longrightarrow \mathrm{X}_{4}$ & 0,147 & 7,608 & 3,151 & 0,003 & Significant \\
$\mathrm{X}_{2} \longrightarrow \mathrm{X}_{4}$ & $-0,072$ & 2090,237 & $-1,020$ & 0,314 & Not Significant \\
$\mathrm{X}_{3} \longrightarrow \mathrm{X}_{4}$ & 0,970 & 0,018 & 13,864 & 0,000 & Significant \\
\hline
\end{tabular}

Sources: Data processed, 2020

The error value (e) needs to be calculated to complete the diagram. This study has two error values (e), namely e1 from the substructure regression equation 1 and e2 from the substructure regression equation 2 . The e 1 structure uses R2 from the substructure regression equation 1 and $\mathrm{e} 2$ is calculated using $\mathrm{R} 2$ from the regression equation substructure 2 . The value $\mathrm{e}_{1}=\sqrt{1-R_{1}^{2}}$ and $\mathrm{e}_{2}=\sqrt{1-R_{2}^{2}}$. The value $\mathrm{e}_{1}=\sqrt{1-0,906}=0,3065941943$ and $\mathrm{e}_{1}=\sqrt{1-0,942}=$ 0,2408318916 .

Table 4

Sobel test results

\begin{tabular}{lcl}
\hline The Effect of Variables & Indirect Effect Coefficient & Sobel Value \\
\hline $\mathrm{X}_{1}-\mathrm{Y}$ & 0,054 & 2,0992 \\
$\mathrm{X}_{2}-\mathrm{Y}$ & $-0,026$ & 0,9180 \\
$\mathrm{X}_{3}-\mathrm{Y}$ & 0,352 & 2,8810 \\
\hline
\end{tabular}

Source: SPSS Test Output and Data Processing, 2020

Table 4 shows the results of the Sobel test. The significance of the indirect effect can be determined by comparing the Sobel value with the $\mathrm{Z}$ table value which is 1.96 . The Sobel test results show a value greater than the $\mathrm{Z}$-table value, this indicates that the intervening variable, namely capital expenditure, can play a significant role. Table 4 shows that 
the investment variables and Original Local Government Revenue (PAD) have a significant effect on regional financial independence through capital expenditures, while GRDP has an insignificant effect on regional financial independence through capital spending.

Table 5

Coefficient of the direct, indirect and total effect

\begin{tabular}{lccc}
\hline Effect & $\begin{array}{c}\text { Direct Coef. } \\
\text { Effect }\end{array}$ & $\begin{array}{c}\text { Indirect Effect } \\
\text { (Through Capital Expenditures) }\end{array}$ & Total Effect \\
\hline $\mathrm{X}_{1} \longrightarrow \mathrm{Y}$ & $-0,104$ & 0,054 & $-0,158$ \\
$\mathrm{X}_{2} \longrightarrow \mathrm{Y}$ & 0,269 & $-0,026$ & 0,454 \\
$\mathrm{X}_{3} \longrightarrow \mathrm{Y}$ & 0,428 & 0,352 & 0,621 \\
$\mathrm{X}_{4} \longrightarrow \mathrm{Y}$ & 0,363 & $-0,363$ & \\
$\mathrm{X}_{1} \longrightarrow \mathrm{X}_{4}$ & 0,149 & $-0,149$ & $-0,072$ \\
$\mathrm{X}_{2} \longrightarrow \mathrm{X}_{4}$ & $-0,072$ & - & \\
$\mathrm{X}_{3} \longrightarrow \mathrm{X}_{4}$ & 0,970 & $-0,970$ & \\
\hline
\end{tabular}

Source: SPSS test output and data processing, 2020

\section{Effect of investments on capital expenditures}

Investment has a significant positive effect on capital spending. The regression results of the effect of investment (X1) on capital expenditure (X4) obtained a beta coefficient of 0.147 with a significance of 0.003 . The results show that the significance value is less than 0.05 and the beta coefficient is positive, it indicates that investment has a positive and significant effect on capital spending.

\section{The effect of GRDP per capita on capital expenditure}

GRDP per capita has no significant negative effect on capital expenditure. The regression results show that the beta coefficient of the regression of the effect of GRDP per capita (X2) on capital expenditure (X4) is -0.072 with a significance of 0.314 . The results show that the significance is greater than 0.05 and the beta coefficient is negative, it can be explained that the GRDP per capita has a negative and insignificant effect on capital expenditure.

\section{The influence of Original Local Government Revenue (PAD) on capital expenditure}

Original Local Government Revenue has a significant positive effect on capital expenditure. Based on the regression results of the effect of Original Local Government Revenue (X3) on capital expenditure (X4), the beta coefficient is 0.970 with a significance of 0.000 . The results show that the significance value is less than 0.05 and the beta coefficient is positive, so the regression results show that the Original Local Government Revenue has a significant positive effect on capital spending.

\section{The effect of capital expenditure on regional financial independence}

There is a positive and significant effect of capital spending on regional financial independence. The regression results of the effect of capital expenditure (X4) on regional financial independence (Y) obtained a beta coefficient of 0.363 with a significance of 0.005 . The results show that the significance value is less than 0.05 and the beta coefficient is positive, it indicates that capital expenditure has a positive and significant effect on regional financial independence.

\section{The effect of investment on regional financial independence}

Investment has a negative and significant effect on regional financial independence. Based on the regression results of the effect of investment (X1) on regional financial independence (Y), the beta coefficient is -0.104 with a significance of 0.016 . The results show that the significance value is less than 0.05 and the beta coefficient is negative, it means that investment has a negative and significant effect on regional financial independence.

Yusiawati, D. ., \& Marhaeni, A. . (2020). Effect of investment, GRDP percapita, and original local government revenue on regional financial independence through capital expenditure as intervening variables. International Research Journal of Management, IT and Social Sciences, 7(6), 96-108. https://doi.org/10.21744/irjmis.v7n6.1016 
The effect of GRDP per capita on regional financial independence

There is a significant positive effect of GRDP per capita on regional financial independence. The regression results of the effect of GRDP per capita (X2) on regional financial independence (Y) obtained a beta coefficient of 0.269 with a significance of 0.000 . The results show that the significance value is less than 0.05 and the beta coefficient is positive, it indicates that the GRDP per capita has a positive and significant effect on regional financial independence.

\section{The influence of Original Local Government Revenue (PAD) on regional financial independence}

Original Local Government Revenue has a positive and significant effect on regional financial independence. Based on the regression results of the effect of Original Local Government Revenue (X3) on regional financial independence $(\mathrm{Y})$, the beta coefficient is 0.428 with a significance of 0.002 . The results show that the significance value is less than 0.05 and the beta coefficient is positive, it means that the Original Local Government Revenue has a positive and significant effect on regional financial independence.

The indirect effect of investment on regional financial independence with capital expenditure as an intervening variable

Investment has a positive and significant effect on regional financial independence through the capital expenditure variable. Capital expenditure can function as a mediating variable in the effect of investment on regional financial independence. Districts / Cities in Bali Province during the research period, from 2014 to 2018, can realize regional financial independence by increasing the value of an investment in their regions through government capital expenditures to support facilities and infrastructure so that the investment climate can develop rapidly. Investment in regencies/cities in Bali Province is an indicator of the good performance of the government in allocating the APBD which is right on target and used optimally. The increase in investment in a region indicates that the region will need capital expenditures allocated by the government to support higher investment growth. Investment has a major effect on the revenue of a region because it will have an impact on economic growth, increased employment, and people's purchasing power (Batik, 2013; Chung et al., 1998; Gordon \& Smith, 1992). Economic development is a function of investment in terms of investment or an economic factor that can be measured quantitatively. Investment can affect the economy of a region so that it will have an impact on regional revenues. Large regional revenues will create regional financial independence because dependence on the central government can be minimized so that local governments can play a major role in managing their regions. There are three main missions in the implementation of regional autonomy and decentralization, namely (Mardiasmo, 2014), creating efficiency and effectiveness of regional resource management, increasing the number of public services, and community welfare. Local governments must be able to manage and use their regional finances effectively and efficiently in the context of implementing their regional governments, for example, an optimal presentation of capital expenditures so that the government can support regional economic growth through investment.

The effect of GRDP per capita indirectly on regional financial independence with capital expenditure as an intervening variable

GRDP has a negative and insignificant effect on regional financial independence through the capital expenditure variable. Capital expenditures cannot function as a mediating variable in the effect of GRDP on regional financial independence. Districts / Cities in Bali Province during the research period, from 2014 to 2018, unable to achieve regional financial independence by increasing GRDP. in the region through government capital expenditures. Soebagyo (2007) explains that regional economic development, both carried out by the government and the private sector to improve the welfare of its population, can be assessed from the magnitude of the GRDP growth rate. Yasa \& Hariyadi (2014), in their research, explain that capital expenditure which has increased every year has not been able to have a significant effect on GRDP because the large allocation of direct expenditure compared to indirect expenditure for public interests is not balanced so that high capital expenditure has not been able to increase GRDP. in regencies/cities in Bali Province. The absence of a significant correlation between GRDP and capital expenditures will have an impact on regional financial independence. Districts / Cities in the Province have not been able to increase the GRDP value so that it has a negative and insignificant effect on regional financial independence through inefficient capital expenditures. 
The effect of Original Local Government Revenue (PAD) indirectly on regional financial independence with capital expenditure as an intervening variable

Original Local Government Revenue (PAD) has a positive and significant effect on regional financial independence through the capital expenditure variable. Capital expenditure can function as a mediating variable in the influence of Original Local Government Revenue on regional financial independence. Districts / Cities in Bali Province during the research period, from 2014 to 2018, can realize regional financial independence by increasing Original Local Government Revenue in their regions through government capital spending. Original Local Government Revenue (PAD) is one of the assets used by local governments to finance regional development. Original Local Government Revenue, which is a source of the regional revenue, is related to economic growth (Kurniawan et al., 2017). Tambunan (2006), states that if the local revenue increases, the funds owned by the regional government will be more and the regional financial independence will increase so that local governments have a high opportunity to develop the regional economy. A region that has a high level of Original Local Government Revenue can allocate funds through an optimal capital expenditure budget to support its region to improve the regional economy so that it will have an impact on the increased Original Local Government Revenue as well. The government will allocate funds in the form of a capital expenditure budget in the APBD to increase fixed assets. Capital expenditure allocation aims to facilitate regional needs for facilities and infrastructure, smooth implementation of local government duties, and improve public services. The utilization of expenditure should be allocated in a productive form such as development (Mawarni \& Abdullah, 2013). Regional revenues should be allocated more for public services, which is the government's contribution to increasing regional revenue through an efficient capital expenditure budget that is intended for the development of public services so that economic growth can be created as seen from the development of investment in the regions. The independence of local governments in managing the budget is used as the basis for optimizing regional revenues through the Original Local Government Revenue (PAD) sector.

\section{The trend of Regional Financial Independence in the Regency / City of Bali Province}

It is important to assess the trend of autonomous regional financial independence to determine the direction of the development of this financial dimension. A Regency / City autonomous region in a certain year may not be able to fulfill its financial independence, but by looking at the positive trend from this financial dimension, confidence is obtained, even though it is slow but there is an opportunity towards ideal financial independence. From the calculation of the KKD ratio, the ratio of regional financial independence is as in the table below:

Table 6

The Autonomous Regional Financial Independence Ratio Regency / City in Bali Province

\begin{tabular}{llrrrrr}
\hline No. & Regency / City & 2014 & 2015 & 2016 & 2017 & 2018 \\
\hline 1. & Badung & $79 \%$ & $80 \%$ & $82 \%$ & $84 \%$ & $84 \%$ \\
2. & Bangli & $10 \%$ & $10 \%$ & $10 \%$ & $10 \%$ & $11 \%$ \\
3. & Denpasar & $40 \%$ & $43 \%$ & $42 \%$ & $49 \%$ & $45 \%$ \\
4. & Buleleng & $14 \%$ & $14 \%$ & $14 \%$ & $21 \%$ & $16 \%$ \\
5. & Jembrana & $11 \%$ & $11 \%$ & $11 \%$ & $10 \%$ & $12 \%$ \\
6. & Tabanan & $20 \%$ & $19 \%$ & $18 \%$ & $23 \%$ & $20 \%$ \\
7. & Gianyar & $30 \%$ & $3 \%$ & $31 \%$ & $37 \%$ & $38 \%$ \\
8. & Klungkung & $12 \%$ & $13 \%$ & $13 \%$ & $14 \%$ & $17 \%$ \\
9. & Karangasem & $19 \%$ & $19 \%$ & $30 \%$ & $13 \%$ & $14 \%$ \\
\hline
\end{tabular}

Source: Data Processing, 2020

Based on the level of financial independence of the district/city autonomous regions in Bali Province, such as the results of the regional financial independence ratios in table 6 above, it can be mapped the relationship patterns of the central government regional autonomous districts/cities in Bali Province as shown in table 7 below:

Yusiawati, D. ., \& Marhaeni, A. . (2020). Effect of investment, GRDP percapita, and original local government revenue on regional financial independence through capital expenditure as intervening variables. International Research Journal of Management, IT and Social Sciences, 7(6), 96-108. https://doi.org/10.21744/irjmis.v7n6.1016 
Table 7

The Patterns of Relations between the Central Government and the Autonomous Regions Regency / City in Bali Province

\begin{tabular}{lllllll}
\hline No. & Regency/City & 2014 & 2015 & 2016 & 2017 & 2018 \\
\hline 1. & Badung & Delegative & Delegative & Delegative & Delegative & Delegative \\
2. & Bangli & Instructive & Instructive & Instructive & Instructive & Instructive \\
3. & Denpasar & Consultative & Consultative & Consultative & Consultative & Consultative \\
4. & Buleleng & Instructive & Instructive & Instructive & Instructive & Instructive \\
5. & Jembrana & Instructive & Instructive & Instructive & Instructive & Instructive \\
6. & Tabanan & Instructive & Instructive & Instructive & Instructive & Instructive \\
7. & Gianyar & Consultative & Instruktif & Consultative & Consultative & Consultative \\
8. & Klungkung & Instructive & Instructive & Instructive & Instructive & Instructive \\
9. & Karangasem & Instructive & Instructive & Consultative & Instructive & Instructive \\
\hline
\end{tabular}

Source: Data Processing, 2020

Amin \& Thrift (2000), states that the percentage of trends is used if you want to see the development of a company. In calculating the percentage, one year is used as the base year. If a year is chosen as the base year, then the data in that year is expressed as 100, which means 100 percent, and similar data in the following year is expressed as a percentage of the base year data. From this explanation, the trend of regional financial independence can be formulated as follows:

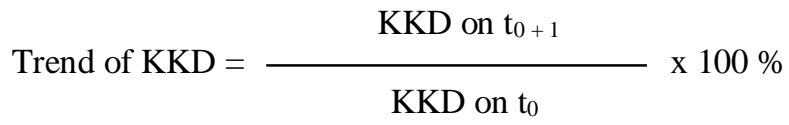

From the calculation of the ratio of regional financial independence in table 6, with the base year 2014, the trend of financial independence from 2015 to 2018 is as shown in table 8 below.

Table 8

The Trend of Autonomous Regional Financial Independence Regency / City in Bali Province

\begin{tabular}{llllll}
\hline No. & Regency / City & 2015 & 2016 & 2017 & 2018 \\
\hline 1. & Badung & $102,12 \%$ & $102,46 \%$ & $102,60 \%$ & $99,50 \%$ \\
2. & Bangli & $102.46 \%$ & $100,33 \%$ & $94,94 \%$ & $115,94 \%$ \\
3. & Denpasar & $107,45 \%$ & $95,58 \%$ & $118,01 \%$ & $91,40 \%$ \\
4. & Beleleng & $100 \%$ & $95,94 \%$ & $151,53 \%$ & $79,01 \%$ \\
5. & Jembrana & $99,97 \%$ & $96,80 \%$ & $97,36 \%$ & $112,82 \%$ \\
6. & Tabanan & $93,07 \%$ & $95,22 \%$ & $128,59 \%$ & $85,61 \%$ \\
7. & Gianyar & $9,87 \%$ & $1052,17 \%$ & $116,36 \%$ & $104,96 \%$ \\
8. & Klungkung & $110,72 \%$ & $95,44 \%$ & $110,40 \%$ & $123,86 \%$ \\
9. & Karangasem & $100 \%$ & $153,95 \%$ & $44,08 \%$ & $103,82 \%$ \\
\hline
\end{tabular}

Source: Data Processing, 2020

The trend of Financial Independence of the Regency / City Autonomous Region in Bali Province for the period 2014 to 2018 can be described as follows:

1) Badung Regency

There is an increasing trend in the ratio of regional financial independence in the Badung Regency from 2014, which was 79 percent, in 2015 it was 80 percent, 2016 was 82 percent, 2017 was 84 percent and in 2018 it was 84 percent. The pattern of relations between the central government and autonomous regions in the Badung Regency has a pattern of delegative relations during the period 2014 to 2018 . This means that there is no central government intervention because the regions are truly capable and independent in carrying out regional autonomy affairs. The central government is ready and with full confidence to delegate financial autonomy to 
regional governments. The trend/tendency of regional financial independence in Badung Regency from 2015 was 102.12 percent, 2016 was 102.46 percent, 2017 was 102.60 percent and in 2018 it was 99.50 percent. The percentage of regional financial independence in the Badung Regency is more than 100 percent and has increased from year to year only in 2018 has experienced a decreasing trend. This shows that in general the development of regional financial independence in the Badung Regency from 2014 to 2018 is good.

\section{2) Bangli Regency}

The pattern of relations between the central government and autonomous regions in the Bangli Regency has a pattern of instructive relationships during the period 2014 to 2018. This means that the role of the central government is more dominant than regional financial independence. Meanwhile, the ratio of financial independence for the autonomous region of Bangli Regency from 2014 to 2017 was 10 percent, and in 2018 it was 11 percent. While the trend of regional financial independence in Bangli Regency in 2015 was 102.46 percent, in 2016 it was 100.33 percent, in 2017 it was 94.94 percent and in 2018 it was 115.94 percent. The percentage of regional financial independence in the Bangli Regency is more than 100 percent, except in 2017 experiencing a decreasing trend.

\section{3) Denpasar City}

The ratio of financial independence for the autonomous region of Denpasar City shows a dynamic picture from year to year. In 2014 the ratio of regional financial independence was 40 percent, in 2015 was 43 percent, in 2016 was 42 percent and in 2017 was 49 percent and in 2018 it was 45 percent. The pattern of relations between the central government and the autonomous region of Denpasar City is shown in table 5.6, has a consultative relationship pattern, meaning that the central government has begun to reduce interference and more in providing consultations because the regions are considered to be slightly more capable of implementing regional autonomy. The trend of regional financial independence for Denpasar City with the base year 2014 in 2015 amounted to 107.45 percent, 2016 amounted to 95.58 percent, 2017 amounted to 118.01 percent and in 2018 amounted to 91.40 percent. The percentage of the regional financial independence of Denpasar City in 2015 and 2017 was more than 100 percent, this shows that the development of the regional financial independence of the City of Denpasar is getting better. However, there was a decline in financial independence in 2016 and 2018.

\section{4) Buleleng Regency}

The ratio of financial independence for the autonomous region of the Buleleng Regency has increased in 2017 but in 2018 it has decreased. 2014 to 2016 was 14 percent, in 2017 was 21 percent and in 2018 was 16 percent. The relationship pattern between the central government and the autonomous region of Buleleng Regency has an instructive relationship pattern, which means that the role of the central government is more dominant than the independence of the regional government, where the regions are not able to implement regional autonomy financially. The trend of regional financial independence in the Buleleng Regency with the base year 2014 in 2015 amounted to 100 percent, in 2016 amounted to 95.94 percent, 2017 amounted to 151.53 percent and in 2018 amounted to 79.01 percent. The percentage of regional financial independence in the Buleleng Regency in 2015 and 2017 was more than 100 percent, this shows that the development of regional financial independence in the Buleleng Regency is getting better. However, there was a decline in financial independence in 2016 and 2018.

\section{5) Jembrana Regency}

Shows the ratio of financial independence of the autonomous regions in the Jembrana Regency from 2014 to 2016 the ratio of regional financial independence was 11 percent, in 2017 it was 10 percent, and in 2018 it was 12 percent. The pattern of relations between the central government and the autonomous regions in the Jembrana Regency has an instructive relationship pattern, which means that the role of the central government is more dominant than the independence of the regional government, where the regions are not able to carry out regional autonomy financially. The trend of regional financial independence in Jembrana Regency with the base year 2014 in 2015 amounted to 99.97 percent, 2016 amounted to 96.80 percent, 2017 amounted to 97.36 percent and in 2018 amounted to 112.82 percent. The percentage of Jembrana Regency regional financial independence in 2018 was more than 100 percent, this shows that the development of Jembrana Regency regional financial

Yusiawati, D. ., \& Marhaeni, A. . (2020). Effect of investment, GRDP percapita, and original local government revenue on regional financial independence through capital expenditure as intervening variables. International Research Journal of Management, IT and Social Sciences, 7(6), 96-108. https://doi.org/10.21744/irjmis.v7n6.1016 
independence is getting better. However, from 2015 to 2017 the percentage was below 100 percent. This indicates that an increase will lead to ideal regional financial independence.

6) Tabanan Regency

The ratio of financial independence of the autonomous regions in Tabanan Regency wherein 2014 the ratio of regional financial independence was 20 percent, in 2015 it was 19 percent, in 2016 it was 18 percent, in 2017 it was 23 percent and in 2018 it was 20 percent. The pattern of relations between the central government and the autonomous regions in Tabanan Regency has an instructive relationship pattern, which means that the role of the central government is more dominant than the autonomy of the regional government, where the regions are not able to implement regional autonomy financially. The trend of regional financial independence in Tabanan Regency with the base year 2014 in 2015 amounted to 93.07 percent, in 2016 amounted to 95.22 percent, 2017 amounted to 128.59 percent and in 2018 amounted to 85.61. The percentage of regional financial independence of Tabanan Regency in 2017 was more than 100 percent, this shows that the development of Jembrana Regency's regional financial independence was better than the previous year, namely 2015 and 2016. However, there was a decrease in financial independence in 2018.

\section{7) Gianyar Regency}

The ratio of financial independence for the autonomous region of Gianyar Regency, wherein 2014 the ratio of regional financial independence was 30 percent, 2015 was 3 percent, 2016 was 31 percent, 2017 was 37 percent and 2018 was 38 percent. The relationship between the central government and autonomous regions has a pattern of consultative relationships wherein 2014, 2016, 2017, and 2018 the role of the central government is more dominant than the independence of the regional government, where the regions are unable to implement regional autonomy financially. However, in 2015 it experienced a drastic decline where the role of the central government was more dominant than the role of local governments. The trend of regional financial independence in Gianyar Regency with the base year 2014 in 2015 amounted to 9.87 percent, 2016 amounted to 1052.17 percent, 2017 amounted to 116.36 percent and in 2018 amounted to 104.96 percent. The percentage of regional financial independence in Gianyar Regency in 2017 and 2018 was more than 100 percent, even in 2016 there was a very high surge.

8) Klungkung Regency

The ratio of financial independence of the autonomous regions in Klungkung Regency wherein 2014 the ratio of regional financial independence was 12 percent, in 2015 it was 13 percent, in 2016 it was 13 percent, in 2017 it was 14 percent and in 2018 it was 17 percent. The pattern of relations between the central government and autonomous regions in Klungkung Regency has an instructive relationship pattern, which means that the role of the central government is more dominant than the autonomy of the regional government, where the regions are not able to implement regional autonomy financially. The trend of regional financial independence in Klungkung Regency with the base year 2014 in 2015 amounted to 110.72 percent, 2016 amounted to 95.44 percent, 2017 amounted to 110.40 percent and in 2018 amounted to 123.86 percent. The percentage of regional financial independence of Klungkung Regency from 2015 to 2018 is more than 100 percent, this shows that the development of Jembrana Regency regional financial independence is getting better. Except in 2016, there was a decrease in financial independence.

\section{9) Karangasem Regency}

The ratio of financial independence for the autonomous regions of the Karangasem Regency fluctuates every year. In 2014 the ratio of regional financial independence was 19 percent, in 2015 was 19 percent, in 2016 was 30 percent, in 2017 was 13 percent and in 2018 was 14 percent. The pattern of relations between the central government and autonomous regions in Karangasem Regency has an instructive relationship pattern, which means that the role of the central government is more dominant than the independence of the regional government, where the regions are unable to implement regional autonomy financially. Except in 2016, there was an increase in the pattern of buhungan to consultative, in which the central government has begun to reduce interference and more in providing consultations because regions are considered to be a little more capable of implementing regional autonomy. The trend/tendency of the regional financial independence of Karangasem Regency with the base year 2014 in 2015 was 100 percent, 2016 was 153.95 percent, 2017 was 44.08 percent and in 2018 it was 103.82 percent. The percentage of regional financial independence of Klungkung Regency 
in 2015, 2016, and 2018 was more than 100 percent, this shows that the development of Jembrana Regency's regional financial independence is getting better. Except in 2017, there was a decrease in financial independence.

\section{Conclusion}

Based on the results of the research conducted, it can be explained that investment has a negative and significant effect on regional financial independence. The results of these studies do not support the research hypothesis. GRDP per capita has a positive and significant effect on regional financial independence and supports the research hypothesis. Original Local Government Revenue (PAD) has a positive and significant effect on regional financial independence. The results support the hypothesis that capital expenditure has a positive and significant effect on regional financial independence. The results are in line with the research hypothesis. Investment has a positive and significant effect on capital spending. These results support the research hypothesis. GRDP per capita has no significant negative effect on capital expenditure. The results of the study are not in line with the research hypothesis. Original Local Government Revenue (PAD) has a positive and significant effect on capital spending and supports the research hypothesis. Capital expenditures can mediate the effect of investment on regional financial independence. Capital expenditures cannot mediate the effect of GRDP per capita on regional financial independence. Capital spending can mediate the influence of Original Local Government Revenue (PAD) on regional financial independence.

The suggestions that can be given to the Regency / City Government in Bali Province are expected to optimize the revenue from the existing potential income. Local governments must look for possible alternatives to overcome their lack of financing, and this requires the creativity of the regional financial executing apparatus to find new sources of financing both through financing cooperation programs with private parties and also programs to increase the Original Local Government Revenue, for example, the establishment of sector BUMD potential to reduce regional dependence on assistance from central and provincial parties. For further researchers, it is hoped that they can add other variables so that they can broaden the scope of the research and can obtain comparisons of different research results. Researchers are also advised to do replicas in future studies. Replication can be done because there are inconsistent research results and do not support the research hypothesis that has been previously formulated

\section{Conflict of interest statement}

The authors declared that they have no competing interests.

Statement of authorship

The authors have a responsibility for the conception and design of the study. The authors have approved the final article.

\section{Acknowledgments}

We are grateful to two anonymous reviewers for their valuable comments on the earlier version of this paper.

Yusiawati, D. ., \& Marhaeni, A. . (2020). Effect of investment, GRDP percapita, and original local government revenue on regional financial independence through capital expenditure as intervening variables. International Research Journal of Management, IT and Social Sciences, 7(6), 96-108. https://doi.org/10.21744/irjmis.v7n6.1016 


\section{References}

Adi, P. H. (2006). Hubungan antara pertumbuhan ekonomi daerah, belanja pembangunan dan pendapatan asli daerah. Simposium Nasional Akuntansi IX, 23-26.

Amin, A., \& Thrift, N. (2000). What kind of economic theory for what kind of economic geography? Antipode, 32(1), 4-9.

Badruddin, R. (2012). Ekonomika Otonomi Daerah Edisi 1. UPP STIM YPKN: Yogyakarta.

Batik, K. (2013). Analisis Pengaruh Investasi, PDRB, Jumlah Penduduk, Penerimaan Pembangunan, dan Inflasi terhadap Pendapatan Asli Daerah (PAD) di Kabupaten Lombok Barat. Jurnal Ekonomi Pembangunan, 11(1), 125147.

Chung, K. H., Wright, P., \& Charoenwong, C. (1998). Investment opportunities and market reaction to capital expenditure decisions. Journal of Banking \& Finance, 22(1), 41-60. https://doi.org/10.1016/S03784266(97)00021-6

Gordon, L. A., \& Smith, K. J. (1992). Postauditing capital expenditures and firm performance: the role of asymmetric information. Accounting, Organizations and Society, 17(8), 741-757. https://doi.org/10.1016/03613682(92)90002-A

Halim, A. (2004). Manajemen keuangan daerah. Yogyakarta: UPP AMP YKPN.

Hamdi, H., \& Sbia, R. (2013). Dynamic relationships between oil revenues, government spending and economic growth in an oil-dependent economy. Economic Modelling, 35, 118-125. https://doi.org/10.1016/j.econmod.2013.06.043

Kawedar, W., Rohman, A., \& Handayani, S. (2008). Akuntansi Sektor Publik: Pendekatan Penganggaran Daerah dan Akuntansi Keuangan Daerah. Semarang: Badan Penerbit UNDIP.

Kurniawan, A. I., Militina, T., \& Suharto, R. B. (2017). Pengaruh Investasi Swasta dan Pengeluaran Pemerintah serta Tenaga Kerja Terhadap Pendapatan Asli Daerah dan Pertumbuhan Ekonomi. Jurnal Inovasi, 3(2), 68-77.

Liu, Z. (2002). Foreign direct investment and technology spillover: Evidence from China. Journal of comparative Economics, 30(3), 579-602. https://doi.org/10.1006/jcec.2002.1789

Mardiasmo. (2014). Akuntabilitas Dan Transparansi. Yogyakarta

Mawarni, D., \& Abdullah, S. (2013). Pengaruh Pendapatan Asli Daerah dan Dana Alokasi Umum terhadap Belanja Modal serta Dampaknya terhadap Pertumbuhan Ekonomi Daerah (Studi pada Kabupaten dan Kota di Aceh). Jurnal Akuntansi ISSN, 2302, 0164.

Narayan, P. K. (2005). The government revenue and government expenditure nexus: empirical evidence from nine Asian countries. Journal of Asian Economics, 15(6), 1203-1216. https://doi.org/10.1016/j.asieco.2004.11.007

Rante, M. S. M., \& Praminto, A. (2017). Analisis Kemandirian Keuangan Daerah.

Romadhoni, P., Faizah, D. Z., \& Afifah, N. (2018). Pengaruh Produk Domestik Regional Bruto (PDRB) Daerah Terhadap Pertumbuhan Ekonomi dan Tingkat Pengangguran Terbuka di Provinsi DKI Jakarta. Jurnal Matematika Integratif, 14(2), 113-120.

Soebagyo. (2007). Analisis pengaruh kebijakan moneter dan kebijakan fiskal regional terhadap stabilitas harga dan pertumbuhan ekonomi regional di Jawa Timur. Buletin Ekonomi Moneter dan Perbankan, 4(9), 55-99.

Sunariani, N. N., Maheswari, A. I. A., \& Pemayun, A. G. P. (2019). Grand investment of tourism sector effort to make many villas and hotels for expanding work opportunities on budgeting. International research journal of management, IT and social sciences, 6(6), 43-49.

Tambunan, T. (2006). Upaya-upaya meningkatkan daya saing daerah. In Makalah Seminar. Pasca sarjana Universitas Sriwijaya.

Todaro, M. P. \& Smith, S. C. (2006). Pembangunan Ekonomi, Erlangga, Jakarta.

Undang-Undang Nomor 32 tahun 2004 Tentang Perimbangan Keuangan Pusat Kepada Daerah

Yasa, I. N. M., \& Hariyadi, E. (2014). Pengaruh PAD terhadap PDRB dan Belanja Modal Kabupaten/Kota di Provinsi Bali. E-Jurnal Ekonomi Pembangunan Universitas Udayana, 3(12), 44497. 